\author{
한국 동해 밍크고래, \\ Balaenoptera acutorostrata의 자원개체수 추정 \\ 박겸준*·안용락·김장근·최석관·문대연·박지은 \\ 국립수산과학원 고래연구소
}

\title{
Abundance Estimates of the Minke Whale, Balaenoptera acutorostrata, in the East Sea, Korea
}

\author{
Kyum Joon Park*, Yong Rock An, Zang Geun Kim, \\ Seok Gwan Choi, Dae Yeon Moon and Ji Eun Park \\ Cetacean Research Institute, 139-29 Maeam-Dong, \\ Ulsan 680-050, Korea
}

\begin{abstract}
Line transect data from sighting surveys conducted in the East Sea, Korea in 2000, 2002, 2003, 2005 and 2006 were analysed to estimate densities and numbers of minke whale. The half-normal model was fit to the survey in 2000 and the uniform model was the most fitable to the survey in 2002 and 2006, and the surveys in 2003 and 2005 were fit by the hazard-rate model. The estimated density of minke whale in the survey in 2000 was estimated as 0.026 individuals $/ \mathrm{km}^{2}{ }_{2}(\mathrm{CV}=0.409 ; 95 \% \mathrm{CI} 0.011-0.065)$ and was higher than the survey in 2002 estimated as 0.018 individuals $/ \mathrm{km}^{2}(\mathrm{CV}=0.329 ; 95 \%$ CI: $0.009-0.034)$. The estimated density of minke whale in the survey in 2003 was estimated as 0.033 individuals $/ \mathrm{km}^{2}(95 \%$ CI: 0.008-0.139) with the highest CV 0.760. The highest density was estimated in the survey in 2005 with 0.053 individuals $/ \mathrm{km}^{2}$ (95\% CI: $\left.0.020-0.141\right)$. The Lowest CV $(0.306)$ was estimated in the survey in 2006 with 0.025 individuals $/ \mathrm{km}^{2}$ (95\% CI: 0.014-0.046). A total of 500 bootstrap samples were generated within each stratum. Density, CV and $95 \%$ CI of each surveys were increased than analytic results except the survey in 2003. There were no increasing or decreasing annual trends in the density of minke whales observed during the study period. A long-term monitor and survey is needed to assess project minke whale abundance in the East Sea.
\end{abstract}

Key words : Line transect, Minke whale, East Sea, Density, Abundance

서 론

밍크고래 (Balaenoptera acutorostrata)는 적도에서 극해까 지 전 대양에 분포하며, 체장은 최대 약 $8.6 \mathrm{~m}$ 까지 성장하여 크기가 수염고래류 중 가장 작다 (Jefferson et al., 2007). 북태평 양에 분포하는 밍크고래는 mtDNA 분석과 (Wada, 1984; Wada et al. 1991) 외부형태적 특징인 가슴지느러미의 흰색대를 비교 해 (Kato et al., 1992) 크게 3개의 계군으로 나누는데, 동해-황해 -동중국해에 분포하는 계군과 오호츠크해-서북태평양에 분포 하는 계군 (북태평양 동경 $180^{\circ}$ 이서 지역), 북태평양 동부 계군 (북태평양 동경 $180^{\circ}$ 이동)으로 나눈다 (Horwood, 1990).

한반도 주변의 밍크고래는 인접국에 의해 이용되어 왔는데 1932년 일본에 의한 포경기록이 있으며 (Matsuura, 1936), 한국 근해 포경어업은 1946년부터 시작되어 1986년 국제포경위원 회 (International whaling commission : IWC)에서 상업포경 모라토리움을 선포할 때까지 행해졌다 (Brownell, 1981; Gong and Hwang, 1984).

상업포경 모라토리움으로 고래류의 포획이 금지되고 20년 이 지난 현재에는 고래류의 발견과 혼획 또는 좌초 보고가

\footnotetext{
*Corresponding author: mogas@nfrdi.go.kr
}

빈번해져 일반인의 관심이 높아졌을 뿐만 아니라 고래류에 의한 어장교란, 조업방해 등의 민원이 증가하고 있다. IWC에 서도 기구의 설립 목적에 맞는 역할을 회복하기 위해 고래자 원을 다른 자원과 마찬가지로 지속적으로 이용하는데 필요한 기능을 수행할 것을 공표하는 결의안을 채택하였다 (IWC, 2006).

밍크고래는 IWC에서 가장 많이 거론되는 종으로 포경을 찬성하는 회원국들은 자원개체수가 증가하여 이용가능한 정 도로 회복되었다고 주장하며 포경을 반대하는 회원국들은 위 험성을 보다 배제한 자원평가와 시뮬레이션을 완성하기 전에 는 포경을 재개할 수 없다고 주장하고 있다 (IWC, 2006). IWC 에서 완성하고자하는 고래관리 방식은 개정관리방식 (Revised management procedure : RMP)으로 자원평가 모델에서 불확실 성에 의한 위험을 배제하기 위해 만들어졌다 (Cooke, 1994). 이 방식을 완성하기 위해서는 첫 번째, IWC의 과학위원회에서 발전시킨 조사와 분석 방법을 표준방법으로 규정하고 이에 따른 조사와 분석 결과를 통해 개정관리방식 안을 만든다. 두 번째, 만들어진 개정관리방식에 대한 모의실험을 수행하여 향후 100 년간 자원의 동태에 관한 평가작업을 하고 자원감소 와 같은 위험성이 없으면 채택하게 된다 (IWC, 2001). 

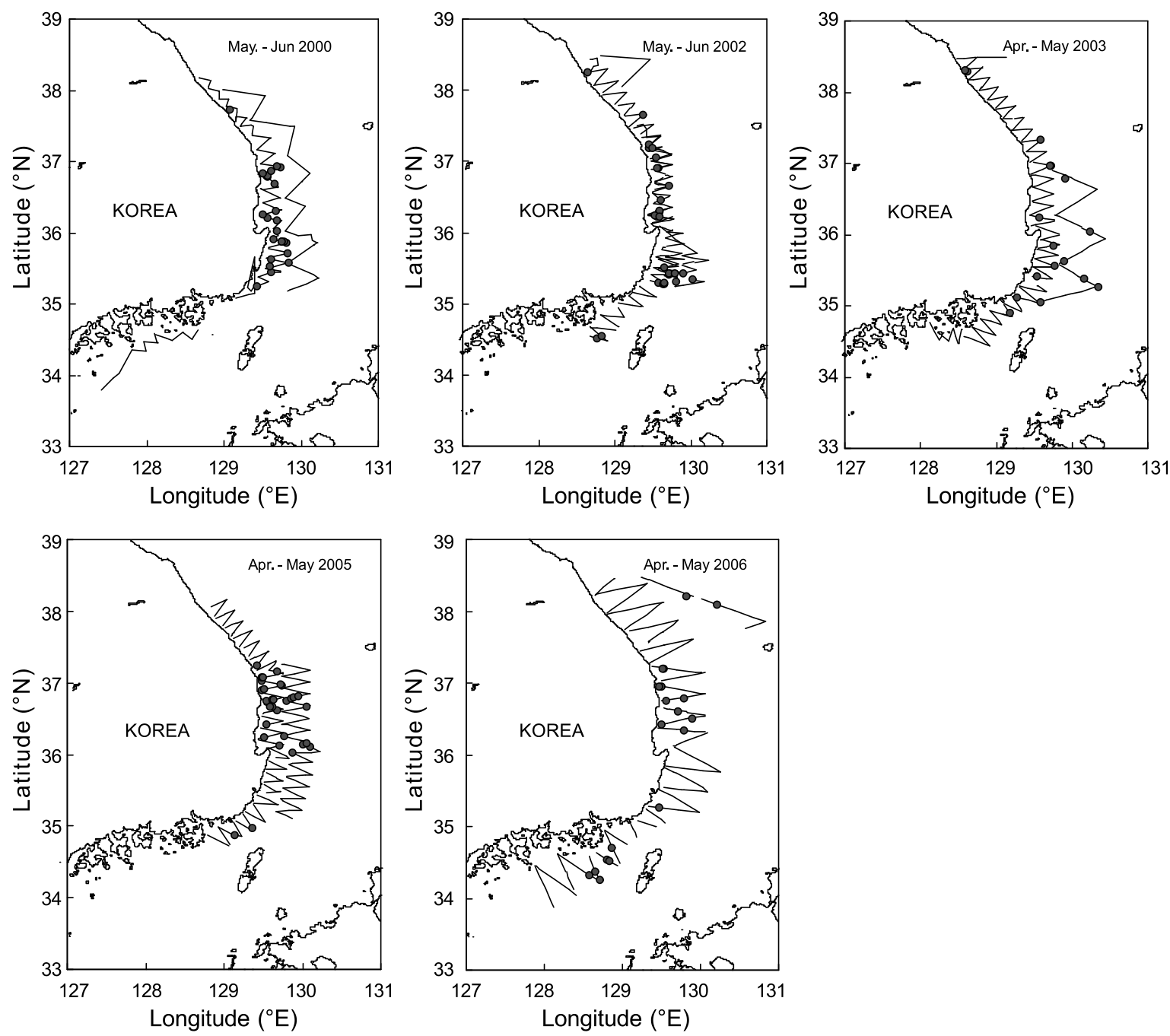

Fig. 1. Completed survey lines (solid lines) and the sighting locations (circles) of minke whale in the East Sea in the surveys in 2000, 2002, 2003, 2005 and 2006.

우리나라에서 밍크고래의 자원개체수에 대한 연구는 Sohn et al. (2001)이 2000년 IWC의 과학위원회에 조사계획을 승인 받고 과학위원회 감독관의 승선 하에 실시한 황해 목시조사 결과만 있을 뿐 동해와 동중국해에서의 평가는 보고되지 않았 다.

따라서 본 연구는 2000년부터 2006년까지 수행된 목시조사 를 통해 동해에 분포하는 밍크고래의 자원개체수를 추정하고 그 변화를 알아보는데 목적이 있다.

\section{재료 및 방법}

\section{조사해역}

밍크고래의 자원개체수와 변동을 추정하기 위해서 우리나 라 동해연안을 따라 Fig. 1과 같이 2000년부터 2006년까지 5 회에 걸쳐 목시조사를 수행하였다. 2000 년에서는 5월 11 일부
터 6월 1 일까지 위도 $34^{\circ} 24^{\prime}-37^{\circ} 45^{\prime} \mathrm{N}$, 경도 $128^{\circ} 03^{\prime}-130^{\circ} 10^{\prime} \mathrm{E}$ 사이의 해역을 조사하였으며, 2002년에는 5월 18 일부터 6월 7 일까지 위도 $34^{\circ} 25^{\prime}-37^{\circ} 45^{\prime} \mathrm{N}$, 경도 $128^{\circ} 03^{\prime}-130^{\circ} 27^{\prime} \mathrm{E}$ 사이의 해역을 조사하였다. 2003년에는 4월 21일부터 5월 18일까지 위도 $34^{\circ} 24^{\prime}-38^{\circ} 40^{\prime} \mathrm{N}$, 경도 $128^{\circ} 27^{\prime}-130^{\circ} 31^{\prime} \mathrm{E}$ 사이의 해역을 조사하였고, 2005년에는 4월 26일부터 5월 25일까지 위도 $34^{\circ} 27^{\prime}-38^{\circ} 51^{\prime} \mathrm{N}$, 경도 $128^{\circ} 35^{\prime}-131^{\circ} 30^{\prime} \mathrm{E}$ 사이의 해역을, 2006

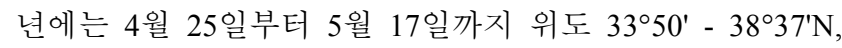
경도 $127^{\circ} 40^{\prime}-130^{\circ} 50^{\prime} \mathrm{E}$ 사이의 해역을 각각 조사하였다 (Table 1).

\section{조사설계}

조사선은 모든 조사에서 국립수산과학원의 시험조사선 탐 구3호 $(360 \mathrm{G} / \mathrm{T})$ 를 사용하였으며, 조사선의 마스트에 수면으 로부터 $11.5 \mathrm{~m}$ 의 망통을 설치하여 주관측대로 사용하였고 
Table 1. Summary of survey effort and sightings for the minke whales, Balaenoptera acutorostrata, in the East Sea, Korea. Standard deviation is provided in parentheses. Encounter rate in clusters each $\mathrm{km}$

\begin{tabular}{cccccccc}
\hline \multirow{2}{*}{ Year } & \multirow{2}{*}{$\begin{array}{c}\text { Survey } \\
\text { area }\left(\mathrm{km}^{2}\right)\end{array}$} & $\begin{array}{c}\text { Survey } \\
\text { line }(\mathrm{km})\end{array}$ & $\begin{array}{c}\text { Number of } \\
\text { sightings }\end{array}$ & & \multicolumn{2}{c}{$\begin{array}{c}\text { Perpendicular } \\
\text { distance }(\mathrm{km})\end{array}$} & $\begin{array}{c}\text { Encounter } \\
\text { rate }(\mathrm{n} / \mathrm{km})\end{array}$ \\
\hline 2000 & $27,971.2$ & $1,313.6$ & 25 & $\begin{array}{c}0.344 \\
(0.506)\end{array}$ & 2.189 & 0.019 \\
& & & & 0.291 & & \\
2002 & $24,262.8$ & $2,165.5$ & 30 & $\begin{array}{c}0.291) \\
(0.26)\end{array}$ & 1.354 & 0.014 \\
2003 & $27,655.0$ & $2,003.1$ & 16 & $\begin{array}{c}0.267 \\
(0.400)\end{array}$ & 1.604 & 0.008 \\
2005 & $22,989.3$ & $1,927.6$ & 28 & $\begin{array}{c}0.274 \\
(0.309)\end{array}$ & 1.219 & 0.015 \\
2006 & $51,339.8$ & $1,981.3$ & 20 & $\begin{array}{c}0.152 \\
(0.126)\end{array}$ & 0.424 & 0.010 \\
\hline
\end{tabular}

수면으로부터 $8 \mathrm{~m}$ 높이에 있는 탑브릿지를 보조관측대로 사 용하였다. 목시관측은 과거 포경업에 종사하여 목시 경력이 30년 정도인 전문탐경원 4명이 수행하였으며 연구원 3-5명도 관측과 기록을 실시하였다. 전문탐경원은 망통과 상갑판에서 2명씩 교대로 관측하였고 연구원은 상갑판에서 관측과 기록, 접근 및 조사선 항로 복귀 등의 지시를 내렸다. 관측은 주로 맨눈으로 수행하였으며 보조로 망원경 (Nikon, 7×50 IF)을 사용하였다.

조사지역은 Hiby and Hammond (1989)에 따라서 자원개체 수의 분산을 추정하여 정확도를 높이고 조사별로 조사 수행율 의 변화에 따른 파라메터 추정을 용이하게 하기위해 조사지역 을 직사각형 (조사블럭)으로 나누어 층화된 샘플추출 (Stratified sampling)을 수행하였다. 나누는 기준은 밍크고래의 밀도가 등밀하다는 가정 하에 연안과 근해로 나누고 연안을 균등한 조사영역을 갖게 하는 기준으로 조사기간과 조사선의 입출항 및 묘박 환경을 고려하여 조사별로 4 개에서 11 개의 조사블럭으로 나누었다. 조사선이 항해할 조사라인은 선박을 이용한 조사에서 주로 이용되는 조사블럭 안에 톱날모양으로 선을 그리는 지그재그 패턴으로 설계하였는데, 이 방법은 평행 선 패턴에 비해 조사노력량이 작을 수 있지만 선박을 이용한 조사의 특성상 조사노력을 균등하게 수행하고 조사라인간의 이동에 따른 시간과 노력의 소비를 막을 수 있다. 각 조사블럭 의 밑변에서 무작위로 시작점을 설정하고 각 조사라인이 등각 을 이루도록 설계하였다 (Hiby and Hammond, 1989; Fig. 1).

조사자료는 Buckland et al. (2001)의 직선횡단조사 (Line-transect) 자료수집방법에 따라 수집되었는데, 조사선으 로부터 발견된 밍크고래까지의 각도와 거리를 맨눈으로 추정 하여 기록하였으며 보조도구로 거리측정기를 사용하였다 (Laser 1200S, Nikon). 관측자의 거리 추정 능력을 향상시키기 위해 조사 전 또는 조사 중 훈련을 실시하였다. 훈련은 정확한 레이더 측정을 위하여 레이더 반사판을 부착한 부이를 띄워 놓고 관측자에게 거리를 측정하게 하는 방법으로 실시하였다.

분석

목시조사 자료는 정규 직선횡단조사 방법에 따라 분석되었
으며, 컴퓨터 프로그램인 DISTANCE Ver.5.0 (Thomas et al., 2005)을 사용하였다. 조사노력 중에 발견된 밍크고래의 발견 각도와 거리는 조사라인으로부터의 수직거리를 계산하는데 사용되었으며 분산을 작게하기 위해 원거리로부터 $5 \%$ 에 있 는 수직거리자료를 절삭하였다 (Buckland et al., 2001). 절삭한 수직거리 빈도분포를 통해 발견율의 변화를 모델링하여 수직 거리 0 에서의 확률밀도함수 $f(0)$ 를 추정하였다. 사용된 모델 은 Uniform 모델 (식 1)과 Half-normal 모델 (식 2), Hazard-rate 모델 (식 3)이며, 모델의 유연성을 높이기 위해 각각 3 개의 보정항 (Cosine, Simple polynomial, Hermit polynomial)을 적용 하였다 (Stuart and Ord 1987).

Uniform 모델 : $1 / w$

여기서 $w$ 는 목표종이 발견된 가장 원거리.

Half-normal 모델 : $\exp \left(-x^{2} / 2 \sigma^{2}\right)$

여기서 $x^{2}=$ 수직거리의 제곱, $\sigma^{2}=\sum_{i=1}^{n} x_{i}^{2} / n$,

Hazard-rate 모델 : $1-\exp \left(1(x / \sigma)^{-b}\right.$

여기서 $b$ 는 형태 파라미터, $\sigma$ 는 단위 파라미터.

모델선택은 Akaike's Information Criterion (AIC)을 사용하 였고 AIC 추정값이 가장 낮은 모델을 선택하였다 (Akaike, 1985).

무리의 크기 $\left(\overline{s_{i}}\right)$ 는 발견된 무리의 크기를 선택된 모델에서 추정된 수직거리에 따른 발견율 $g(x)_{i}$ 로 회귀하여 추정하였다.

$i$ 년도 밍크고래의 밀도 $\left(\widehat{D}_{i}\right)$ 는 모델별로 추정된 수직거리 0 에서의 확률밀도함수 $\left(\hat{f}(0)_{i}\right)$ 와 무리의 크기 $\left(\overline{s_{i}}\right)$, 발견율 (발견건수/해리) 값을 사용하여 식 4와 같이 추정하였으며, 분산은 식 5 와 같이 추정하였다 (Burnham et al., 1980).

$$
\begin{aligned}
& \widehat{D_{i}}=\frac{n_{1} \cdot \hat{f}(0)_{i} \cdot \overline{s_{i}}}{2 \cdot L_{i}} \\
& \widehat{\operatorname{var}}\left(\widehat{D}_{i}\right)=D_{i}^{2} \cdot\left[\frac{\widehat{\operatorname{var}}\left(2 n_{i}\right)}{n_{i}^{2}}+\frac{\widehat{\operatorname{var}}\left\{\hat{f}(0)_{i}\right\}}{\left\{\hat{f}(0)_{i}^{2}\right\}}+\frac{\widehat{\operatorname{var}}\left(\overline{s_{i}}\right)}{s_{i}^{2}}\right]
\end{aligned}
$$

여기서 $n_{i}=$ 목시횟수, $\overline{s_{i}}=$ 무리의 평균 크기, $\hat{f}(0)_{i}=$ 수직거 리가 0 일 때의 확률밀도함수 추정값, $\mathrm{L}=$ 총 조사거리 (Nautical mile)이다.

밍크고래의 자원개체수 $\left(\widehat{N}_{i}\right)$ 는 밀도 $\left(\widehat{D}_{i}\right)$ 에 조사면적 $\left(A_{i}\right)$ 을 곱하여 식 6 과 같이 추정하였으며 분산 $\widehat{\operatorname{var}}\left(\widehat{N}_{i}\right)$ 은 식 7 과 같이 추정하였다.

$$
\widehat{N}_{i}=\frac{n_{1} \cdot \hat{f}(0)_{i} \cdot \overline{s_{i}} \cdot A_{i}}{2 \cdot L_{i}}
$$




$$
\widehat{\operatorname{var}}\left(\widehat{N}_{i}\right)=N_{i}^{2} \cdot\left[\frac{\widehat{\operatorname{var}}\left(2 n_{i}\right)}{n_{i}^{2}}+\frac{\widehat{\operatorname{var}}\left\{\hat{f}(0)_{i}\right\}}{\left\{\hat{f}(0)_{i}^{2}\right\}}+\frac{\widehat{\operatorname{var}}\left(\overline{s_{i}}\right)}{s_{i}^{2}}\right]
$$

$A_{i}=$ 조사해역 면적(Nautical mile square)

$95 \%$ 신뢰구간은 Burnham et al. (1987)에 따라 $\hat{N}$ 와 $\hat{D}$ 를 대수정규분포한다고 가정하고 상한 $(\hat{N} \cdot C)$ 과 하한 $(\hat{N} / C)$ 을 추정하였다.

$$
C=\exp \left[1.96 \sqrt{\operatorname{var}\left(\log _{e} \hat{N}\right)}\right]
$$

여기서 $\operatorname{var}\left(\log _{e} \hat{N}\right)=\log _{e}\left[1+\frac{\operatorname{var}(\hat{N})}{\widehat{N}^{2}}\right.$ 이다.

또한, 비모수적 Bootstrap 방법을 사용하여 각 조사의 샘플 을 재샘플링하고 밀도와 개체수, 표준오차와 신뢰구간을 추정 하였다 (Efron and Tibshirani, 1993). 재샘플링은 각 조사에서 각 조사블럭의 조사라인을 단위로 이루어졌으며, 재샘플링을 통해 모든 블럭에서 총 500회에 걸쳐서 Bootstrap 샘플을 생성 하였다.

조사라인 상의 발견율은 1 로 일정하다고 가정하였다 $[\mathrm{g}(0)=1]$.

$$
\text { 결 과 }
$$

조사

각 연도별 조사 결과는 Table 1과 같으며 조사항정과 밍크고 래의 발견위치는 Fig. 1과 같다. 조사면적은 2000년에 27,971.2 $\mathrm{km}^{2}, 2002$ 년에 $24,262.8 \mathrm{~km}^{2}, 2003$ 년에 $27,655.0 \mathrm{~km}^{2}$ 2005년에 $22,989.3 \mathrm{~km}^{2} 2006$ 년에 $51,339.8 \mathrm{~km}^{2}$ 로 각각 조사되었다. 1 차 목시노력은 2000 년에 $1,313.6 \mathrm{~km}, 2002$ 년 조사가 $2,165.5 \mathrm{~km}$, 2003 년 조사가 $2,003.1 \mathrm{~km}, 2005$ 년 조사가 $1,927.6 \mathrm{~km}, 2006$ 년 조사가 $1,981.3 \mathrm{~km}$. 이었다. 발견횟수는 2002년 조사가 30회로 가장 많이 발견되었고 그 다음으로 2005년 조사가 28회, 2000 년 조사가 25회, 2006년 조사가 20회 2003년 조사가 16회 순이었다. 조사라인에서 발견무리까지의 수직거리평균 (표준 편차)은 2000 년 조사가 $0.344 \mathrm{~km}(0.506)$ 로 가장 멀었고 그 다음으로 2002 년 조사가 $0.291 \mathrm{~km}(0.291), 2005$ 년 조사가 $0.274 \mathrm{~km}(0.309), 2003$ 년 조사가 $0.267 \mathrm{~km}(0.400)$ 순이었으며

Table 2. Sighting data after right-truncation at $5 \%$ of the observation and estimated expected mean cluster size. Coefficient variation is shown in parentheses. $r=$ correlation coefficient, $p=p$-value of a t-test of the regression estimates of $\log _{\mathrm{e}}$ cluster-size against detection function

\begin{tabular}{ccccc}
\hline Year & $\begin{array}{c}\text { Number of } \\
\text { sightings }\end{array}$ & $\begin{array}{c}\text { Encounter rate } \\
(\mathrm{n} / \mathrm{km})\end{array}$ & $\begin{array}{c}\text { Mean cluster } \\
\text { size }\end{array}$ & $\begin{array}{c}\text { Estimated expected } \\
\text { mean cluster size }\end{array}$ \\
\hline 2000 & 24 & $0.018(37.86)$ & $1.083(5.32)$ & $1.117(4.19)[r=0.198, p=0.823]$ \\
2002 & 28 & $0.013(30.92)$ & $1.071(4.63)$ & $1.102(3.59)[r=0.178, p=0.817]$ \\
2003 & 15 & $0.007(28.19)$ & $1.067(6.25)$ & $1.160(5.29)[r=0.262, p=0.827]$ \\
2005 & 27 & $0.014(25.70)$ & $1.037(3.57)$ & $1.127(2.69)[r=0.335, p=0.956]$ \\
2006 & 19 & $0.010(25.43)$ & $1.158(7.42)$ & $1.244(6.24)[r=0.303, p=0.897]$ \\
\hline
\end{tabular}
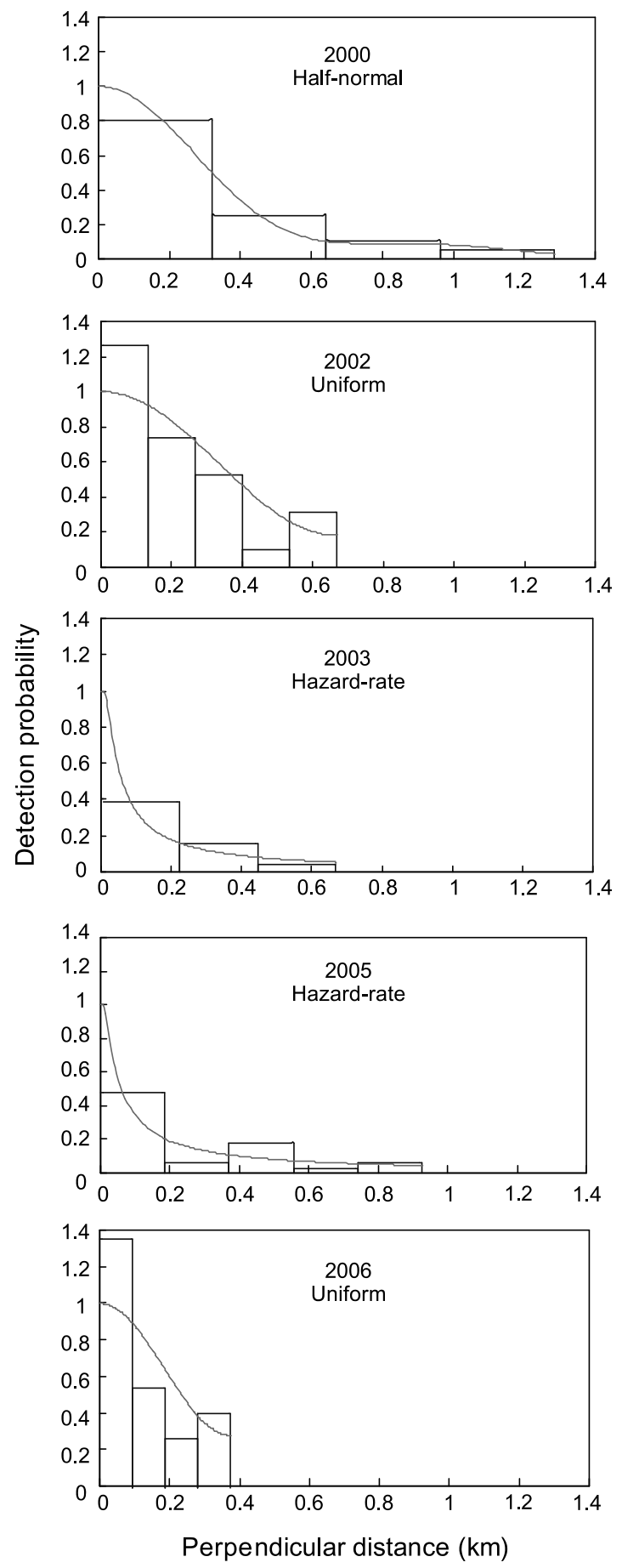

Fig. 2. Histograms of perpendicular distance and fitted detection functions for best AIC (akaike information Criterion) selected model of the surveys in 2000, 2002, 2003, 2005 and 2006.

2006 년 조사가 $0.152 \mathrm{~km}(0.126)$ 로 거리가 가장 가까웠다. 조사 거리당 밍크고래 발견율도 2000년 조사가 0.019로 가장 높았 으며 2003년 조사가 0.008 로 가장 낮았다. 


\section{확률밀도함수}

이상점에 의한 영향과 분산을 줄이기 위해 목시자료를 원거 리에서 $5 \%$ 까지의 자료를 절삭하였으며 그 결과 사용된 자료 는 Table 2와 같으며 수직거리에 따른 빈도분포는 Fig. 2와 같다 (Buckland et al. 2001). 샘플의 수와 거리에 따라서 4-7개 의 구간으로 나누어졌으며 조사라인 가까이에서의 발견빈도 가 가장 높고 거리에 따라서 감소하는 전형적인 거리표집에 의한 빈도분포를 보였다. 2002 년 조사에서 2 개의 발견이 절삭 된 것을 제외하고 모두 1 개의 발견이 절삭되었다. 발견된 무리 의 평균크기 (변동계수)는 2006년 조사가 1.158 (7.42)마리로 가장 컸고 그 다음으로 2000년 조사가 1.083 (5.32)마리였으며, 2005년 조사가 1.037 (3.57)마리로 가장 작았다.

Table 3. Parameter estimates of each model used to fit the perpendicular distance data for minke whale. AIC = akaike information criterion, ESW = effective strip width. $\mathrm{f}(0)=$ probability density function at zero. $\mathrm{P}=$ detection probability

\begin{tabular}{cccccc}
\hline Year & Model & AIC & ESW & $\mathrm{f}(0)$ & $\mathrm{P}$ \\
\hline \multicolumn{2}{c}{ Half-normal } & -9.20 & 0.386 & 2.56 & 0.30 \\
2000 & Hazard & N/A & N/A & N/A & N/A \\
& Uniform & -7.58 & 0.356 & 2.78 & 0.28 \\
\hline \multicolumn{2}{c}{ Half-normal } & -28.73 & 0.386 & 2.59 & 0.58 \\
2002 & Hazard & -29.50 & 0.334 & 3.00 & 0.50 \\
& Uniform & -29.51 & 0.396 & 2.53 & 0.59 \\
\hline \multicolumn{2}{c}{ Half-normal } & -17.69 & 0.328 & 3.05 & 0.49 \\
2003 & Hazard & -20.25 & 0.130 & 7.71 & 0.19 \\
& Uniform & -18.05 & 0.285 & 3.51 & 0.43 \\
\hline \multicolumn{2}{c}{ Half-normal } & -14.64 & 0.362 & 2.76 & 0.39 \\
2005 & Hazard & -18.19 & 0.149 & 6.71 & 0.16 \\
& Uniform & -17.73 & 0.420 & 2.38 & 0.45 \\
\hline \multicolumn{2}{c}{ Half-normal } & -38.75 & 0.245 & 4.08 & 0.66 \\
2006 & Hazard & -38.41 & 0.190 & 5.26 & 0.51 \\
& Uniform & -39.58 & 0.238 & 4.20 & 0.64 \\
\hline
\end{tabular}

Table 4. Summary of density $\left(\mathrm{D}=\right.$ individuals $\left./ \mathrm{km}^{2}\right)$ and abundance $(\mathrm{N})$ estimates of minke whale in the East Sea from 2000 to 2006. $\mathrm{CV}=$ Coeffient Variance, $\mathrm{CI}=$ Confidential Interval

\begin{tabular}{cccccc}
\hline \multirow{2}{*}{ Year } & \multirow{2}{*}{\begin{tabular}{c} 
Point \\
\cline { 5 - 6 } 2000
\end{tabular}} & \multirow{2}{*}{ CV } & \multicolumn{2}{c}{$95 \% \mathrm{Cl}$} \\
\cline { 5 - 6 } & $\mathrm{N}$ & 0.026 & \multirow{2}{*}{40.9} & 0.011 & 0.065 \\
& $\mathrm{~N}$ & 738 & & 299 & 1,824 \\
\hline \multirow{2}{*}{2002} & $\mathrm{D}$ & 0.018 & \multirow{2}{*}{32.9} & 0.009 & 0.034 \\
& $\mathrm{~N}$ & 437 & & 230 & 830 \\
\hline \multirow{2}{*}{2003} & $\mathrm{D}$ & 0.033 & \multirow{2}{*}{76.0} & 0.008 & 0.139 \\
& $\mathrm{~N}$ & 926 & & 223 & 3,843 \\
\hline \multirow{2}{*}{2005} & $\mathrm{D}$ & 0.053 & \multirow{2}{*}{52.4} & 0.020 & 0.141 \\
& $\mathrm{~N}$ & 1,349 & & 500 & 3,640 \\
\hline \multirow{2}{*}{2006} & $\mathrm{D}$ & 0.025 & \multirow{2}{*}{30.6} & 0.014 & 0.046 \\
& $\mathrm{~N}$ & 1,286 & & 707 & 2,340 \\
\hline
\end{tabular}

각 조사자료에 적용된 Half-normal 모델과 Hazard-rate 모델, Uniform 모델의 AIC값은 Table 3과 같다. 2000년 조사의 경우, Half-normal 모델에서 AIC가 가장 낮은 -9.20으로 추정되었으 며, Hazard-rate 모델은 추정이 되지 않았다. 2002년 조사에서 는 Uniform 모델이 -29.51로 $\mathrm{AIC}$ 가 가장 작게 추정되었으며, 2003년 조사의 경우 Hazard-rate 모델에서 AIC가 -20.25로 가 장 작았다. 2005년 조사의 경우 Hazard-rate 모델에서 AIC가 -18.19로 가장 작았으며, 2006년 조사에서는 Unifom 모델에서 $\mathrm{AIC}$ 가 -39.58으로 가장 작았다. 따라서 2000년 조사에서는 Half-normal 모델이 선택되었으며2002년 조사와 2006년 조사 는 Uniform 모델, 2003년 조사와 2005년 조사는 Hazard-rate 모델이 각각 선택되었다. 각 모델에 의해 추정된 $\mathrm{ESW}$ (Effective strip width : 유효조사녋이)와 $f(0)$ [거리 0 에서의 발견확률밀도함수 $=\frac{1}{E S W}$ ], 발견거리 내에서의 발견율 $(\mathrm{P})$ 은 Table 3과 같다. ESW는 2002년 조사가 각각 $0.396 \mathrm{~km}$ 로 가장 높았으며 그 다음으로 2000년 조사가 0.386, 2006년 조사 가 $0.238,2005$ 년 조사가 $0.149,2003$ 년 조사가 0.130 순이었다. 발견율은 2006년 조사가 0.64으로 가장 높았고 2002년 조사가 $0.59,2000$ 년 조사가 $0.30,2003$ 년 조사가 $0.19,2005$ 년 조사가 0.16 순이었다. 확률밀도함수 $\mathrm{f}(0)$ 는 2003년 조사가 7.71로 가 장 높았고, 2005년 조사가 6.71, 2006년 조사가 4.20, 2000년 조사가 2.56이었으며, 2002년 조사가 2.53으로 가장 낮았다.

밀도와 개체수

각 조사별 모델에 따른 밀도와 개체수, 변동계수는 Table 4 와 같다. 2000 년 조사의 경우, 밀도가 $0.026 \mathrm{ind} . / \mathrm{km}^{2}(95 \%$ CI: 0.011-0.065), 변동계수는 40.9로 추정되었다. 개체수는 738 (95\% CI: 299-1,824)마리로 추정되었다. 2002년 조사의 경우 밀도가 $0.018 \mathrm{ind} . / \mathrm{km}^{2}$ (95\% CI: 0.009-0.034)로 조사 중 가장 낮게 추정되었으며, 변동계수도 32.9 로 가장 낮게 추정되 었다. 따라서 다른 조사에 비해 $95 \%$ 신뢰구간이 가장 좁았다 (Fig. 3). 개체수도 437 (95\% CI: 230-830)마리로 다른 조사에 비해 가장 낮게 추정되었다. 2003년 조사의 경우 밀도가 0.033 ind. $/ \mathrm{km}^{2}$ (95\% CI: 0.008-0.139)로 추정되었으며 변동계수는 76.0 으로 가장 높았다. 따라서 다른 조사에 비해 $95 \%$ 신뢰구간 도 가장 넓었으며 개체수는 926 (95\% CI: 223-3,843)마리로 추정되었다. 2005년도 조사에서는 밀도가 $0.053 \mathrm{ind} . / \mathrm{km}^{2}(95 \%$ CI: 0.020-0.141)로 다른 연도에 비해 가장 높았고 변동계수는 두 번째로 높은 52.4로 추정되었다. 개체수도 가장 많은 1,349 (95\% CI: 500-3,640)마리로 추정되었다. 2006년 조사의 경우, 밀도가 0.025 ind. $/ \mathrm{km}^{2}$ (95\% CI: 0.014-0.046), 변동계수는 30.6 으로 가장 낮게 추정되었다. 개체수는 $1,286 \quad(95 \%$ CI: 707-2,340)마리로 추정되었다.

Fig. 3에서 밍크고래의 밀도는 뚜렷한 증가나 감소의 경향 을 나타내지는 않았다. 2005년 조사에서 밀도가 가장 높게 추정되고 2003년 조사에서 그 다음으로 높게 추정되었지만 높은 변동계수와 넓은 $95 \%$ 신뢰구간을 나타냈다. Fig. 4에서 개체수로 살펴보면, 역시 2002년 조사에서 가장 적은 개체수 가 추정되었고 2005 년 조사에서 가장 많은 개체수가 추정되었 


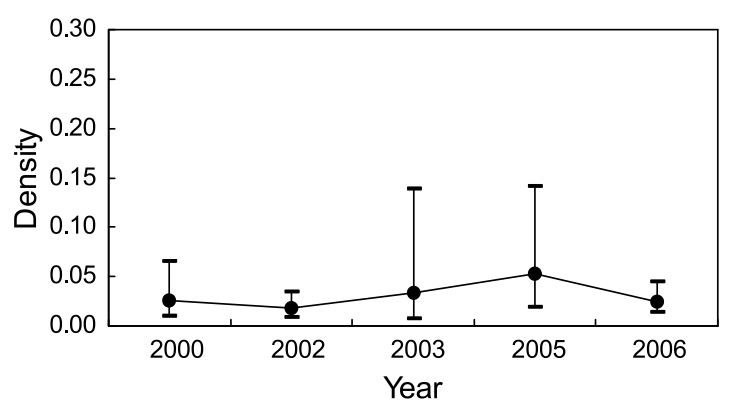

Fig. 3. Annual variations in the density estimates (individuals $/ \mathrm{km}^{2}$ ) and $95 \%$ confidence interval for minke whale in the East Sea.

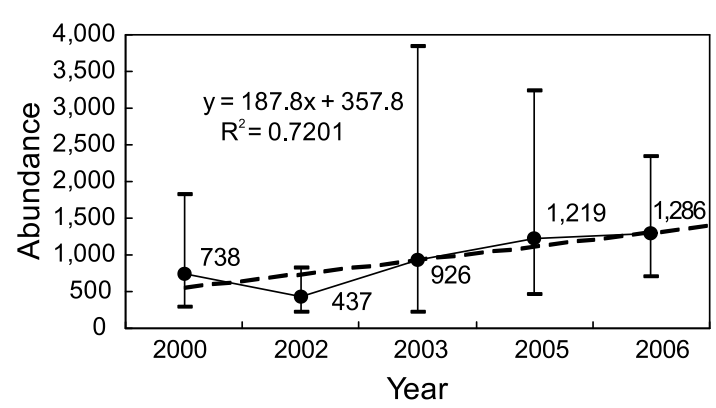

Fig. 4. Annual variations in the abundance estimates (individuals) and 95\% confidence interval for minke whale in the East Sea.

Table 5. Summary of density $\left(\mathrm{D}=\right.$ individuals $\left./ \mathrm{km}^{2}\right)$ and abundance ( $\mathrm{N}=$ individuals) estimated by the non-parametric by the non-parametric bootstrap resampling $(n=500)$ from 2000 to 2006. $\mathrm{CV}=$ Coefficient Variance, $\mathrm{CI}=$ Confidential Interval

\begin{tabular}{cccccc}
\hline \multirow{2}{*}{ Year } & \multirow{2}{*}{ Parameter } & \multirow{2}{*}{ Point estimate } & \multirow{2}{*}{ CV\% } & \multicolumn{2}{c}{$95 \% \mathrm{Cl}$} \\
\cline { 5 - 6 } & & & & Lower & Upper \\
\hline \multirow{2}{*}{2000} & $\mathrm{D}$ & 0.032 & \multirow{2}{*}{58.95} & 0.009 & 0.110 \\
& $\mathrm{~N}$ & 890 & & 256 & 3,093 \\
\hline \multirow{2}{*}{2002} & $\mathrm{D}$ & 0.021 & \multirow{2}{*}{42.55} & 0.009 & 0.048 \\
& $\mathrm{~N}$ & 511 & & 227 & 1,154 \\
\hline \multirow{2}{*}{2003} & $\mathrm{D}$ & 0.033 & \multirow{2}{*}{52.55} & 0.012 & 0.096 \\
& $\mathrm{~N}$ & 919 & & 319 & 2,650 \\
\hline \multirow{2}{*}{2005} & $\mathrm{D}$ & 0.083 & \multirow{2}{*}{84.16} & 0.019 & 0.364 \\
& $\mathrm{~N}$ & 1,907 & & 434 & 8,370 \\
\hline \multirow{2}{*}{2006} & $\mathrm{D}$ & 0.026 & \multirow{2}{*}{46.76} & 0.010 & 0.063 \\
& $\mathrm{~N}$ & 1,329 & & 541 & 3,261 \\
\hline
\end{tabular}

으나, $95 \%$ 신뢰구간은 2003 년 조사가 가장 넓게 추정되었다. 밀도에서는 경향이 없었지만 개체수에서는 증가하는 경향을 보였다.

각 조사의 자료를 비모수적 Bootstrap 방법으로 500개의 자료로 재생성하고 분석한 결과는 Table 5와 같다. 2000년 조사에서 밀도가 0.032 ind. $/ \mathrm{km}^{2}$ (95\% CI: 0.009-0.110), 변동계
수가 58.95로 추정되었으며 개체수는 890 (256-3,093)마리로 추정되어 원 자료보다 높게 추정되었다. 2002년 조사도 마찬 가지로 밀도가 $0.021 \mathrm{ind} . \mathrm{km}^{2}$ (95\% CI: 0.009-0.048), 변동계수 는 42.55로 원 자료보다 높게 추정되었다. 개체수도 511 (227-1,154)마리로 높아졌다. 그러나 2003년 조사의 경우, 밀 도가 $0.033 \mathrm{ind} . / \mathrm{km}^{2}$ (95\% CI: 0.012-0.096), 개체수가 919 (95\% CI: 319-2,650)마리로 원 자료보다 증가하였으나 변동계수는 오히려 52.55로 낮게 추정되었다. 2005년 조사도 밀도와 개체 수가 원 자료보다 높게 추정되어 밀도가 $0.083 \mathrm{ind} . / \mathrm{km}^{2}(95 \%$ CI: 0.019-0.364), 개체수가 1,907 (434-8,370)마리였으나 변동 계수가 크게 증가하여 84.16으로 가장 높았다. 2006년 조사에 서도 밀도가 0.026 ind. $/ \mathrm{km}^{2}$ (95\% CI: 0.010-0.063), 개체수는 1,329 (95\% CI: 541-3,261)마리로 원 자료보다 높게 추정되었 으며 변동계수도 46.76으로 높게 추정되었다 (Fig. 5).

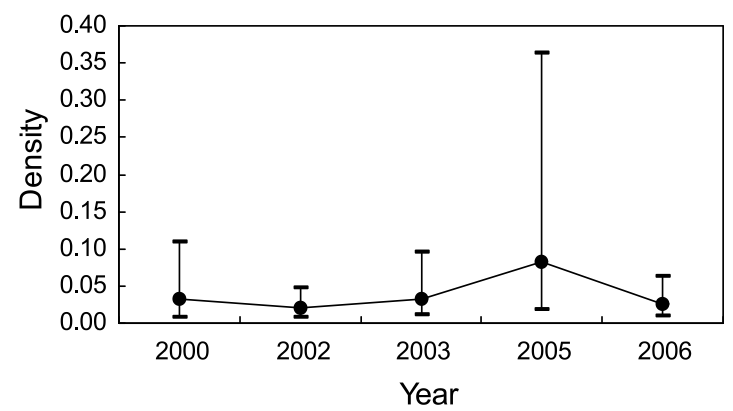

Fig. 5. Annual variations in the density (individuals $/ \mathrm{km}^{2}$ ) and $95 \%$ confidence interval estimated by 500 bootstrap resampled method $(n=500)$.

\section{고 찰}

목시조사는 해양포유류 뿐만 아니라 다른 여러 육상 동물과 식물의 자원량 추정에 사용되는 조사방법이다. 대상이 어떤 종이든 대부분의 조사가 거리에 따른 발견율의 변화를 추정하 기 위해 거리표집을 하기 때문에 거리를 추정하는데 있어서 정확성에 대한 신뢰의 문제가 자주 거론된다 (Cook, 1985). 이를 해결하기 위해 여러 가지 장비가 사용되며 관찰자의 추정값을 시험하여 보정하기도 한다. 또한 부정확한 거리 추 정값에 의한 영향을 줄이기 위해 추정된 거리와 각도를 유사 한 그룹으로 묶는 도말표본법 (Smearing)을 사용하기도 한다. 본 연구에서 측정오차에 대한 평가와 도말표본법이 사용되지 않았지만 조사 전과 조사 간의 테스트와 보조장비의 이용으로 오차를 최소화 하려고 노력하였으며, Chen (1998)은 목시조사 에서 측정오차가 매우 크지 않은 한 자원개체수 추정값의 편의는 전형적으로 작다고 하였다.

2000년부터 시작된 동해연안 목시조사는 2006년까지 평균 (표준편차) $30,843.6 \mathrm{~km}^{2}$ (11,656.7)의 면적을 조사하였다. 조 사면적은 2005 년 조사가 $22,989.3 \mathrm{~km}^{2}$ 로 가장 작았고 2002년 조사가 그 다음으로 작았는데 이들 두 조사는 다른 조사에 비해 노력량은 큰 차이가 없었다 $(P>0.05)$. 따라서 다른 조사에 비해 조사라인의 밀도가 가장 높았는데, 발견횟수도 2002년 
조사가 30회, 2005년 조사가 28회로 다른 조사에 비해 높았다. 조사노력이 많아지면 발견횟수가 증가하는 것은 자연스러운 현상이지만 발견율로 보면 목시노력량이 가장 적은 2000년 조사가 0.019로 가장 높았다 (Table 1). Fig. 1에서 조사가 수행 된 해역을 보면 연안에서 밀도 높게 수행되었고 근해에서의 조사노력이 거의 전무하다. 따라서 제한된 조사기간에 밍크고 래의 분포와 보다 넓은 면적에서의 개체수를 추정하기 위해서 는 조사노력의 밀도를 낮추어 조사 면적을 넓혀야 할 것으로 생각된다.

본 연구에서 발견율함수 $\mathrm{g}(0)$ 을 1 로 가정을 하였으나 발견 율함수 $\mathrm{g}(0)$ 는 독립목시자 관측에 의해 추정되어야 한다. 그러 나 본 연구에서 2002년부터 주관측대를 따로 설치하여 상갑판 을 보조관측대로 사용하였고 발견 종의 확인과 발견샘플수를 확보하기 위하여 독립목시를 수행하지 않았다. 독립목시를 수행하면 $\mathrm{g}(0)$ 를 추정할 수 있지만 Table 2로 봤을 때 분석할 수 있는 샘플이 20 개 이하로 줄어들 가능성이 매우 높다. $\mathrm{g}(0)$ 를 추정하면 보다 정확한 파라메터값이 생기지만 현재의 샘플 수준에서 샘플이 줄어들면 개체수의 추정이 어려워지거나 오차가 커지게 된다. 실제로 분석에 사용된 샘플이 15 개인 2003년 조사는 다른 조사에 비해 변동계수가 76.0으로 제일 높게 추정되었으며 신뢰구간도 제일 컸다. $\mathrm{g}(0)=1$ 로 가정하면 과대추정의 위험을 피할 수 있어 위험관리에 유리한 것으로 생각된다.

각 조사의 자료에 가장 적합한 모델은 2000년 조사가 Half-normal 모델, 2002년과 2006년 조사가 Uniform 모델, 2003년과 2005년 조사는 Hazard-rate 모델이 선택되었다. Park et al. (2007)은 상괭이 (Finless porpoise, Neophocaena phocaenoides) 목시조사 자료분석을 통해 Hazard-rate 모델이 다른 모델에 비해 자원개체수 추정값이 높고 Uniform 모델은 낮게 추정한다고 하였다. 실제로 모든 조사에서 Hazard-rate 모델의 $f(0)$ 추정값이 다른 모델들 보다 높았는데, 2003년과 2005년 조사의 경우 다른 모델보다 추정값이 2 배 이상 높았으 며, 변동계수도 다른 조사에 비해 높게 추정되었다. Fig. 2에서 2003년 조사와 2005년 조사 결과 히스토그램에 Hazard-rate 모델을 사용해 발견율을 모델링하였는데, 발견율이 조사라인 에서 수직거리 약 $0.05 \mathrm{~km}$ 도 평행을 유지하지 못하고 급격하 게 감소하는 경향을 보였다. 이러한 원인은 Fewster et al. (2005)과 Melville and Welsh (2001)의 연구에서와 같이 Hazard-rate 모델 자체의 문제이거나 본 연구의 목시자료의 문제일 수도 있다.

따라서 5 개년의 조사를 통해 수집된 자료가 모집단을 대표 하는 샘플로 잘 수집되었는지와 확률밀도함수와 표준오차, 95\% 신뢰구간을 컴퓨터 시뮬레이션을 통해 추정하고 비교하 기 위해 Bootstrap 방법을 사용하여 각 조사별로 500회의 자료 를 생성하여 분석하였다. Bootstrap 방법에 의한 밀도와 변동 계수는 2003년 조사를 제외하고 분석적 방법에 의한 결과 보다 높게 산출되었다. 2003년 조사에서 밀도는 증가하였지만 변동계수는 오히려 감소하였다. 분석적 방법에 의해 추정된 변동계수는 2003년 조사와 2005년 조사만 50이상으로 추정되
었으나, Bootstrap 방법에 의해 추정된 결과에서는 2000년 조 사의 변동계수도 58.95 로 18.05 증가하였다. 무엇보다 특이한 것은 가장 높은 변동계수와 $95 \%$ 신뢰구간을 보였던 2003년 조사가 재생성한 자료를 통한 분석에서는 오히려 감소하여 2005년 조사보다 낮아졌다는 것이다. 2005년 조사의 변동계수 는 84.16으로 크게 증가하였고 $95 \%$ 신뢰구간도 다른 조사에 비해 크게 증가하였다 (Fig. 4, 5). 결과적으로 2003년 조사에서 수집된 샘플수는 다른 조사에 비해 가장 작았지만 Bootstrap 결과 편의가 크지 않았으며 2005년 조사는 샘플의 수가 2002 년 조사 다음으로 많지만 자료가 편의가 있는 것으로 생각된 다. 2003년 조사와 2005년 조사에서 분석적 방법과 Bootstrap 방법의 결과가 큰 차이를 보이는 이유는 위에서 언급한 것과 같이 발견율이 초기에 급감하여 발견율이 다른 조사에 비해서 크게 낮았기 때문인 것으로 생각된다 (Fig. 2; Table 3). 또한 2003년 조사는 발견개체수가 적었지만 2005년 조사는 발견개 체수가 두 번째로 많음에도 발견율이 가장 작게 추정되었고 유효조사넓이 $(\mathrm{ESW}$ )도 각각 $0.13 \mathrm{~km}$ 와 $0.15 \mathrm{~km}$ 로 추정되었는 데, Bootstrap 방법을 통해 샘플을 재생성하면서 발견된 밍크 고래의 수직거리가 상대적으로 먼 2005년 조사에서는 신뢰구 간이 크게 증가하고 수직거리가 가까웠던 2003년 조사는 신뢰 구간이 감소한 것으로 생각된다.

본 연구를 통해 7년 동안 5 개년의 밍크고래 자원개체수가 추정되었는데 2002년 조사와 2006년 조사 결과는 차이가 있었 지만 $(P<0.05)$ 뚜렷한 증가나 감소의 경향을 보이지는 않았다 $(\mathrm{R}=0.349$; Fig. 3). 밍크고래의 수명은 최대 60세까지이며 먼 거리를 회유하기 때문에 (Jefferson et al., 2003) 밍크고래자원 의 명확한 개체수 변화를 추정하고 평가하기 위해서는 목시노 력의 밀도나 조사기간을 조절하여 조사면적을 넓히고 향후 다년간의 조사와 모니터링이 지속되어야 할 것이다.

$$
\text { 사 사 }
$$

본 연구는 국립수산과학원 고래연구소의 주요과제인 “고 래류 자원 및 생태조사, RP-2009-FR-035” 결과의 일부이며, 본 조사에 참여한 고래연구소 연구원들과 전문탐경인 손남수, 이병욱, 김용필, 이병준, 고 김해진님, 다년간 조사선 운항으로 수고해 주신 탐구3호 전 직원분들게 감사드립니다.

\section{참고문헌}

Akaike H. 1985. Prediction and entropy. In: A Celebration of Statistics. Atkinson AC and Feinberg SE, eds. Springer-Verlag, Berlin, 1-24.

Brownell RL Jr. 1981. Review of coastal whaling by the Republic of Korea. Paper SC/32/Ba6 presented to the IWC Scientific Committee.

Buckland ST, Anderson DR, Burnham KP, Laake JL, Borchers DL and Thomas L. 2001. Introduction to Distance Sampling: Estimating numbers of biological populations. Oxford, New York.

Burnham KP, Anderson DR and Laake JL. 1980. 
Estimation of density from line transect sampling of biological populations. Wildl Mon 72, 1-102.

Chen SX. 1998. Measurement errors in line transect surveys. Biometrixs 54, 899-908

Cooke JG. 1985. Notes on the estimation of whale density from line transects. Rep Int Whal Comm 35, 319-323.

Cooke JG. 1994. Simulation trial of the RMP catch limit algorithm in the presence of adverse external influences on whale populations. Rep Int Whal Comm 45, 113-115.

Efron B and Tibshirani RJ. 1993. An Introduction to the Bootstrap. Chapman and Hall, London, U.K.

Fewster RM, Laake JL and Buckland ST. 2005. Line transect sampling in small and large regions. Biometrics 61, 856-861.

Gong Y and Hwang BN. 1984. Effort, catch and sightings data for the minke whale fishery in Korean waters. Rep Int Whal Comm 37, 281284.

Hiby AR and Hammond PS. 1989. Survey techniques for estimation numbers of cetaceans. Rep Int Whal Comm 11, 47-80, special Issue.

Horwood J. 1990. Biology and Exploitation of the Minke Whale. CRC press. Florida. pp. 238.

IWC (International Whaling Commission). 2001. Report of the scientific committee, Annex D. Report of the sub-committee on the RMP. J Cetacean Res Manag 3 (Suppl.), 90-125.

IWC (International Whaling Commission). 2006. Chair's report of the Fifty-eight annual meeting. Rep Int Whal Comm 57, 46-50.

Jefferson TA, Webber MW and Pitman RL. 2007. Marine Mammals of the World: A comprehensive guide to their identification. Academic Press, London, U.K.

Kato H, Kishiro T, Fujise Y and Wada S. 1992. Morphology of minke whales in the Okhotsk Sea, Sea of Japan and off the east coast of Japan, with respect to stock identification. Rep Int Whal Comm 42, 437-442.

Matsuura Y. 1936. On the lesser rorqual found in the adjacent waters of Japan. Bull Jap Soc Sci Fish 4, 325-330.

Melville GJ and Welsh AH. 2001. Line transect sampling in small regions. Biometrics 57, 11301137.

Park KJ, Kim ZG and Zhang CI. 2007. Abudance estimation of the finless porpoise, Neophocaena phocaenoides, using models of dection function in a line transect. J Kor Fish Soc 40, 201-209.

Sohn H, Kim ZG and Miyashita T. 2001. Abundance estimate of minke whale, Balanoptera acutorostrata, by sighting survey in the Yellow Sea, spring 2001. J Kor Soc Fish Res 4, 51-63.

Stuart A and Ord JK. 1987. Kendall's Advanced theory of Statistics, Vol. 1. Griffin, London. U.K.

Thomas L, Laake JL, Strindberg S, Marques FFC, Buckland ST, Borchers DL, Anderson DR, Burnham KP, Hedley SL, Pollard JH, Bishop JRB and Marques TA. 2005. Distance 5.0. Release "x"1. Research Unit for Wildlife Population Assessment, University of St. Andrews, UK. http://www.ruwpa. stand.ac.uk/distance/

Wada S. 1984. A note on the gene frequency differences between minke whales from Korean and Japandes coastal waters. Rep Int Whal Comm 34, 345-347.

Wada S, Kobayashi T and Numachi K. 1991. Genetic variability and differentiation of mitochondrial DNA in minke whales. Rep Int Whal Comm (Special issue 13), 203-216.

2009년 9월 11일 접수

2009년 11월 25일 수정

2009년 11월 30일 수리 